\title{
INTONATION GROUPS IN ARABIC (MAINLY IN THE HOLY QURAN)
}

\author{
Author \\ Areej Ali Otay
}





\section{Introduction}

This study will be concerned with intonation-groups in Arabic with special reference to the Holy Quran.

The Holy Quran, which turned the Arabic of Quraish into the Arabic language used in literary worke and spread it into areas far beyond Arabia, is an important source for Islamic and Arabic studies. One of these studies has important bearing on Quranic orthoepy, which was developed in 9ilmu tajwid al-Quran, the science of Quranic recitation. The Holy Quran is regarded as a record of Arabic sounds, that will preserve the Arabic sounds forever.

$$
\text { قال الله تعالى ( ما فرطنا في الكتاب من شيء ) }
$$

(We have neglected nothing in the book)

$$
\text { (Al-?na9m:38) }
$$

Kaan and Al-Hlali(1996)

The writing of the Quran is distinguished from the writing of any other Arabic material. Modern punctuation marks became known in Arabic during the last century, and up that now they are not universally adopted in a systematic way. In any case, none of these marks appear in the writing of the Quran. Six pause marks, 9alaamaat al-waqf, are used in the Quran, placed as superscripts above the verse, consider:

1 Sign for a mandatory pause al-waqf al-laazim. e.g .

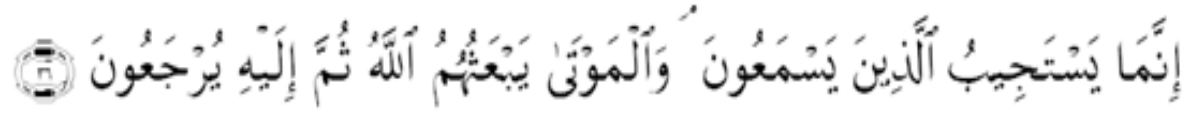

\section{Al-?n9aam:36}

It is only those who listen (to the Message of Prophet Muhammad) will respond (benefit from it), but as for the dead (i.e. disbelievers), Allah will raise them up, then to Him they will be returned (for their recompense). Kaan and AlHlali(1996) 
The mandatory pause comes after يسمعون. Without this mandatory pause, the meaning of the

verse would be distorted for then it would conjoin those who hear, and the dead, as parts of يستجيب respond, which equates the dead and the living in hearing and accepting.

У Sign for prohibited pause - Pal-waqf Pal-mamnuu9. e.g.

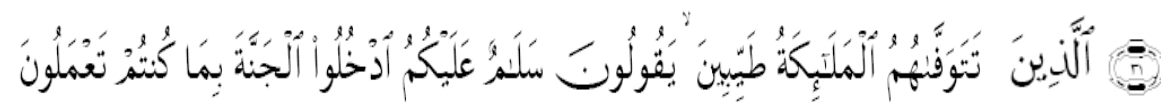

(Annahl :32)

Those whose lives the angels take while they are in a pious state (i.e. pure from all evil, and worshipping none but Allah Alone) saying (to them): Salaamun 9alaaikum (peace be on you) enter Paradise, because of that (the good) which you used to do (in the world). Kaan and Al-Hlali(1996)

It is prohibited to pause at which would leave the sentence unfinished since the remainder of the sentence i.e must cohere where with the agent of the sentence, الملائكة, in the first part of it.

? Sign of optional pause - waqf ja?iz jawaazan mustawiya-lTarafayn. e.g

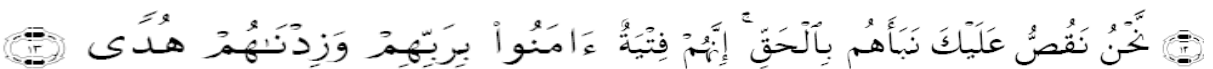

( Al-kahf: 13).

"We shall narrate to thee their story with truth. They were young men who believed in their Lord (Allah), and we increased them in guidance."

"We relate to thee their story in truth: they were youths who believed in their Lord and we advanced them in guidance" The optional pause comes after بالحق "truth". 
Sign of preferred non-pause al-waqf jaa?iz ma9a kawn alwaSl Pawlaa. e.g.,

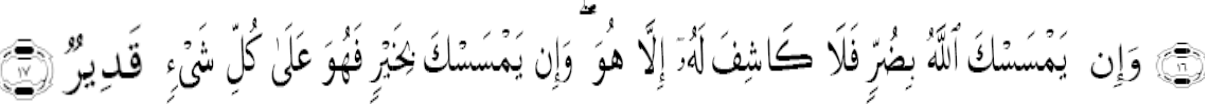

"If Allah touches thee with affliction none can remove it but $\mathrm{He}$; and if $\mathrm{He}$ touches thee with Good, $\mathrm{He}$ is powerful over everything (Al?naam:17). Kaan and Al-Hlali (1996)

This pause comes after إلا هو "but He", for semantic reasons it is preferable to pause at the end of the verse.

تلح Sign of preferred pause - al-waqf jaa?iz wa awlaa. e.g.:

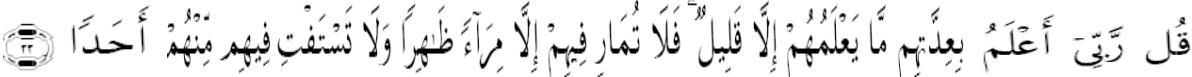

"Say (O Mohammad) My Lord knows best their number; none knows them but a few, so, debate not (about their number) except with the clear proof (which We have revealed to you). And consult not any of them (people of the Scripture Jews and Christians) about (the affair of) the people of the Cave. "(Alkahf: 22) Kaan and Al-Hlali(1996)

It is preferable to pause after إلا قليل "save a few".

$\therefore$ : Sign of selective pause - ta9aanuq al-waqf. If you pause at the former of the two places you may not pause at the other. e.g.

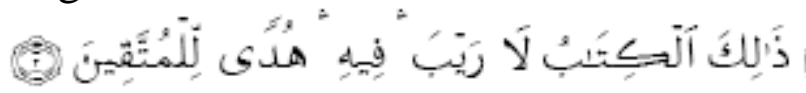

It can be readen either as:

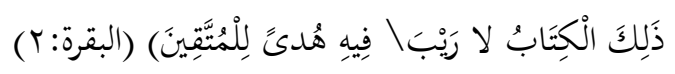

"This is the Book- no doubt. In it there is guidance to those pious believers who fear Allah Much" Kaan and AlHlali(1996)

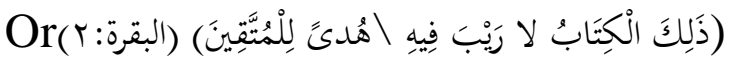

This is the Book wherein there is no doubt, guidance to those pious believers who fear Allah Much" If the reader paused at both places, the meaning would be disrupted. 
It is important in reading the Holy Quran that the reader should learn when he can start and when he can stop or even when to take breath.

Cruttenden (1986:80) says "intonation groups are basically some sort of units of performance. They may represent a unit of planning for the speaker and a unit of presentation by the speaker for the listener". According to this, ton deiodination of the speaker will determen by the massage that sending to the speaker. However there most be a limitation for this division.

In this study pause signs, 9alaamaat al-waqf, are regarded as the boundaries for the reader to make his choice in tone group divisions. Observation of Quranic pause signs is essential for understanding the meaning of Quranic verses.

Non-Quranic Arabic texts may contain punctuation marks which help the reader to dissect the texts into appropriate tone groups but in this case the reader has the freedom to pause at different places for a number of purposes including pausing for breath.

Undoubtedly, the Holy Quran and general Arabic texts share certain intonational features which this study will attempt to delineate, particularly in so far as tone groups and their significance are concerned.

That tone groups in Arabic contribute to the understanding of utterances is unquestionable. Consider the following utterance:

$$
\text { أنا من علي ومن عثمان برئ }
$$

If said as a single tone group, the speaker distances himself from both Ali and Othman. However, if a pause (and a falling tune) is made on the word علي, viz:

$$
\text { أنا من علي \ومن عثمان برئ. - أن }
$$


The speaker would then be understood to associate عثمان and to distance himself from Othman علي himself with

\section{1-1 Significance of the Study}

This study sheds light on intonation groups in Arabic with special reference to the Holy Quran, which will be useful to the study of Arabic intonation in general.

\section{1-2- Methodology}

This study was undertaken with the general aim of demonstrating the relevance and significance of what Mitchell (1975: 70) called a basically inductive approach to the analysis of linguistic meaning. It is true that; "One can never be wholly inductive or exclusively deductive, but it is possible at a given time to be more one than the other", then the inductive approach is the way to treat texts and part texts according to their own merits. "namely that reasonably free, though properly controlled, rein should be allowed to the development and exploitation of contrasts arising out of close observation and textual analysis"

\section{Intonation and meaning}

Intonation is a natural characteristic of any language. It is important not only for good pronunciation but also because it is a way of sending and receiving different messages. Changing our pitch helps us to indicate certainty, uncertainty, enthusiasm, boredom, and so on. We can say Yes but we mean No.

Therefore, speech without intonational features is no more than a machine output. (http://humanities.byu.edu, 2002). Fairbanks and Pronovost (1939) investigate the phonetic features involved in the expression of different emotions: contempt, anger, fear, grief, and indifference.

\section{Grammatical function:}

There are degrees of grammatical function for 
intonation: some structures will be intonationally more restricted than others, and some intonation contrasts will be more frequently used for the purpose of making grammatical contrasts than others (Crystal 1969). If we change the intonation patterns the meaning of the utterance will change as well. Also, different syntactic structures require different intonation like declaratives, interrogatives and imperatives. According to Halliday (1970), there are many intonation patterns which carry a different meaning which is part of English grammar". The choice of tones relates to mood (kind of statements, question...), modality (assessment of the possibility, probability, validity, relevance ...) and governed by all the factors which make up the relation between the speaker and the hearer, in a speech situation" (Halliday 1970: 22-23).

Badawi also investigates the activity of complete contours or pitch movements in relation to single tone-groups and sequences of tone-groups. His analysis technique depends on taking the elements of the pattern, one by one, as tonic, pretonic, etc. Then, he makes a comparison between different kinds of tones. Badawi claims that spontaneous speech cannot be analyzed in complex combination, so he divides it into smaller units. According to this, he came up with three main divisions of speech. 1-'the complete intonations' which he studies under the single tone groups and combination of tone groups. 2- 'the incomplete' and 3'the interrupted'. He uses the terms 'vertical spread' and 'horizontal spread' to differentiate between the two kinds of rise fall called by Halliday as pointed and rounded respectively.

Sorraya (1966) uses the conversational natural speech of the educated Egyptian. He uses the tone as the basic unit. He defines tones as an inventory of significant pitch features. 
He divides tones into different clauses assorted from the minimum to the maximum part of speech like syllable, words, sentences, compound and sequences of tones. He divides tones by distinguishing between them in relation to their tonal, grammatical and attitudinal properties. He gives high attention to available combinations of tone groups that he devotes one chapter to examining the sentence types and their patterns. This way of grouping demands the need for classification of the tones and their frequency in everyday use of speech. He also devoted a chapter for the types of sentences and intonation patterns that are associated with them, as the same sentence can be used in different situations by changing the intonation. He goes over some intonation patterns which might occur with certain types of sentences, e.g. statement, questions, exclamations. He shows that exclamations have rising-falling tone while vocatives have falling-tone and greetings have low-rising tone.

Ghalib (1977) treats the tones of colloquial Iraqi spoken Arabic by dealing with the pitch characteristics, function and emotional coloring of that dialect. He focuses on attitude and how it manipulates intonation. Ghalib states that the description of attitude cannot be controlled, or one cannot associate a particular type of tonal feature with a particular attitude. According to him, differences are classified as a combination of differences in prosodic features, lexical, tonal and textural. He distinguishes between simple and compound tone-groups, and then talks about compound tones and sequences of tones. He recognizes five main tones and sixteen subdivisions of tone and distinguishes six different types of head.

Al-Amayreh (1991), studies the basic intonation patterns in standard and spoken Jordanian Arabic. He adopts Halliday's approach to intonation. He suggests seven tones, 
falling, rising, low rising, falling-rising rounded, risingfalling tone, and two compound tones, falling + low rising and rising- falling rounded + low rising which are in line with the tones established by Halliday (1970). Al-Amayreh claims that the two languages, Arabic and English, have the same tones are also similar for, the semantic and syntactic functions of these tones.

\section{Intonation Definition:}

Intonation has been defined by almost all of the scholars in this field each according to his interest. O'Connor (1954) defines intonation as the tune, the melody, the music of speech where the words do not change the meaning but what changes is the speaker feelings which reflect hislher attitude.

Halliday (1970) asserts that the importance of intonation is in its ability of giving different meanings for the same utterance by changing the intonation.

MccArthy gave a different definition:

Intonation is, of course, the term given to the rise and fall of the pitch of the voice in spoken language that involves a study of the correlation between the intonation patterns that native speakers actually use and the grammatical and situational contexts in which they use them, together with the subtleties of meaning conveyed, whether intentionally or involuntarily, to native hearers. MCCArthy (1956)

Chomsky (1968 p89) states "we may think of language as a set of sentences, each with an ideal phonetic form and an associated intrinsic semantic interpretation. The grammar of the language is the system of rules that specifies this sound meaning correspondence."

From what has been mentioned above, no one can deny the importance of intonation. Many researchers have 
studied the effect of intonation on language acquisition, almost all of those researchers agreed that children learn the intonation patterns of their language very early, usually well before words. Some babies babble using very authentic sounding intonation patterns. Adults almost always respond as if to an intelligent conversation.

\section{The Intonation Unit}

The concept of an intonation unt is described differently by scholars each according to his persuasion, as 'sprechtakt' (Klinghhardt), 'breath-group' (Jones), 'tone-group' (Plamer, Armstrong and Ward, OConnor and Arnold, Halliday), 'rhythm unit' (Pike), 'Phonemic clause' (Trager and Smith), "Tone-unit' (Crystal), "Intonation-group' (Cruttenden), 'intonation Phrase' (Pierrehumbert). These are some of the terms used by those scholars. Though the different terminology may occasionally obscure its identity, the tone group is largely accepted as the domain of phonological, syntactic, and semantic contrast for intonation.

Halliday, (1970 p121) says that; the tone group is a unit of information which is not the same as sentences, or clauses or phrases, but represents a different kind of organization that exists side by side with the structure of sentences. The organization of information, in other words, is not tied to any kind of structure. However, "in many cases, in conversational English, it corresponds to a clause, and this can be taken as the basic pattern: one clause is one tone group unless there is good reason for it to be otherwise". According to this, he presents three systems for the description of intonation in English. In any utterance in English three distinct meaningful choices, or sets of choices, are made which can be, and usually are, subsumed under the heading of "intonation". These are: first, the distribution into tone groups, the number and location of tone group 
boundaries; second, the placing of the tonic syllable, the location, in each tone group, of the pretonic and tonic sections; third, the choice of primary and secondary tone. These three systems are called "tonality", "tonicity" and "tone" respectively.

MCCarthy, (1956) talks about how the beginnings and ends of tone groups are largely determined by grammatical and syntactical considerations by the ways in which the words of a sentence are related to each other, as they succeed one another in time (on the breath stream) or in print (across the page). Then he said that for purposes of analysis the general flow of speech, speech-stream, as it is often called, must be divided into smaller units. These units are convenient to deal with when analyzing intonation.

Cruttenden (1986:130) He estimates: "intonationgroups generally correlate with major syntactic constituents, although a good deal of choice is available to speakers concerning which constituent's intonation-groups should correspond with. Hence we cannot say that syntactic constituency completely predicts intonation-group boundaries".

Boomer $(1965,159)$ investigates what he calls" filled and unfilled pauses" Which are examined according to their position in phonemic clauses i.e. tone groups. According to that hesitation was most frequent after the first word in the clause in regardless of length. Then he related the types of the encoding unit to the position of the hesitation. First, "If the encoding units are single words then hesitations should occur more frequently before those words which involve a difficult decision: i.e. a choice among many alternatives". On the other hand, according to this the hesitations may occur better at the beginning than at the difficult word choice occurs. 
Brown (1977) defines a tone group simply as being bounded by pauses and containing an accented syllable or tonic, which means that there is normally a perceptible pause before and after a tone group that contain just one moving tone, to be found on the last stressed syllable of the last prominent word. From Brown's point of view tone groups serve to indicate syntactic units. As he says (1977:87-8) "the most general and important function of tone group division then must be seen to be the marking off coherent syntactic structures which the listener must process as units"

\section{Arabic Tone Groups}

The intonation of English varies considerably from one social or regional speech community to another. The same thing can be said about the intonation of Arabic. As most of research on Arabic intonation demonstrates the same idea that the intonation of Arabic differs from region to region. Intonation is also influenced by the personal characteristics of the individuals and by their mood and attitude at the time of speaking. Many studies have been done on some varieties of Arabic intonation which give a description of the intonational systems of the dialects investigated.

Arabic linguists have not said much about Arabic intonation. Tammam Hassan (1985) cited in El-Hassan (1991) says that intonation in standard Arabic has not been recorded or studied. Consequently, any study of it to date must inevitably depend on habits of pronunciation pertinent to the colloquial dialect.

It's clear that the Holy Quran doesn't have punctuation marks. There must be an important role played by the reader that makes the Holy Quran more easily understandable. This study is concerned only with how intonation groups in the Holy Quran affect the meaning, by analyzing and comparing them with English intonation groups. 


\section{Tone group in The Holy Quran}

The reading system in the Holy Quran depends on the intonation system. The reader must follow a systematic way in reading the Holy Quran which is governed by the rules of 9ilmu-ttajwiid (the science of recitation) and 9alaamaatulwaqf (pausal signs). The Breath Group, normally speech does not consist of unorganized strings of words, but stretches of words in the utterance of which the breath and tone are integral parts. So, the utterance is divided into breath groups consisting of a group of words uttered in a single breath, where the speaker either stops speaking or draws breath to continue. Somehow this group may or may not correspond to phrases and sentences as recorded in writing or print. The majority of tone groups are analogous more or less to sentences of prose while the rest are of phrasal or lexical length. Lieberman (1967:192) defines the breath group as "the phonetic feature that speakers make use of two segment the train of words into sentences". In other words, it is the phonetic feature that enables a listener to group words into meaningful sentences. So, breath groups are regarded to be a common feature in all human languages.

\section{Grammatical and semantic function of tone groups:}

This study attempts to find out if intonation groups in Arabic generally correlate with major syntactic constituents as in English the aim of talking in Arabic as in any language is communication, which includes giving information and emotions. Words, phrases and sentences join according to the rules of syntax. To analyze any tone group in the Holy Quran, we have to know that dividing utterances into tone groups is a complex system that depends on the interrelation between semantics and grammar. Consider the following verse: 


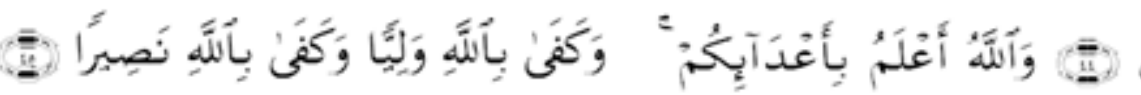

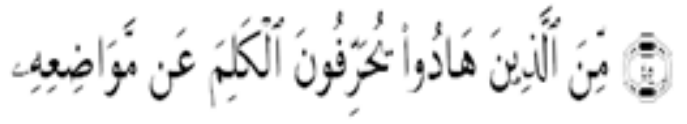 \\ An-Nisa 45-46}

"45-Allah has full knowledge of your enemies, and Allah is Sufficient as Walli (protector), and Allah is Sufficient as a Helper.46- Among those who are Jews, there are some who displace words from (their) right places." Kaan and Al-Hlali(1996)

The above verses correspond to the following elements of structure:

1-S+V+Prepositional phrase 2- V+Prepositional phrase $+\mathrm{V}+$ Prepositional Phrase3- prepositional phrase. $+\mathrm{V}+\mathrm{S}+$ prepositional phrase.

These elements of structure constitute coherent grammatical units, which are not arbitrary or bizarre.

The above verses can be divided into three tone groups ordered in two ways as;

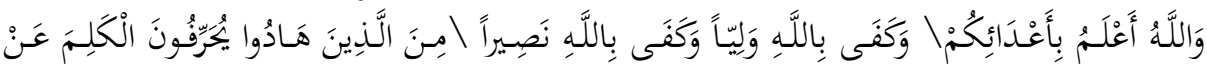

1- These two verses can be read separately where the reader can stop by the end of the verse. Where the meaning will be Allah has full knowledge of your enemies, and Allah is Sufficient as a Walli (protector), and Allah is Sufficient as a Helper.

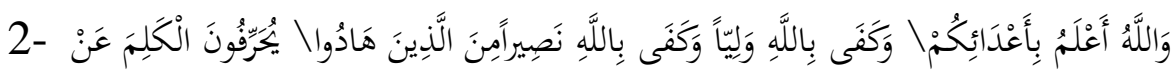

Or: The second verse will mean: Among those who are Jews, there are some who displace words from (their) places. 
The main syntactic element in these two verses is the preposition "from"(من) "from" in the first reading refers to the omitted subject (who) the meaning will be "Among those who are Jews, there are some who displace words from (their) places.

2- The second way of reading is to stop by the word haduu, where the preposition from is means that "Allah has full knowledge of your enemies, and Allah is Sufficient as a Walli (protector), and Allah is Sufficient as a Helper rather than the Jews".

The next two verses are not likely to constitute one tonegroup, because they are separable semantically and syntactically.

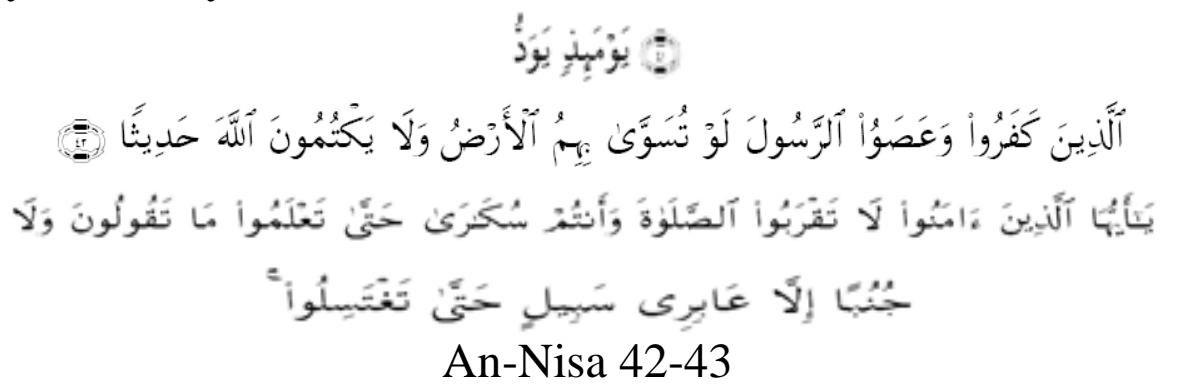

42- On that day those who disbelived and disobeyed the Messenger (Muhammad) will wish that they were buried in the earth, but they will never be able to hide a single fact from Allah. 43- O you who believe! Approach not As-Salaat (the prayer) while you are in a drunken state until you Know (the meaning) of what you utter, nor while you are in a state of Janaaba (i.e. in a state of sexual impurity and have not yet taken a bath). Kaan and Al-Hlali(1996)

Verses 41 and 42 cannot consist one tone group because the reader should stop at the end of the first verse where the meaning is complete by the word حديثا. It will mean "on that day those who disbelieved and disobeyed the 
Messenger (Muhammad PBUH) will wish that they were buried in the earth, but they will never be able to hide a single fact from Allah" at the end of this verse the subject will finish and by the beginning of the next verse another topic will be introduced.

This kind of pause is called as "Alwaqfu alkaafi", where there is a strong relation between the pause and syntactic structure which govern the beginning of the next verse. The following two-tone groups illustrate this kind of pause which is determined by the grammatical rules.

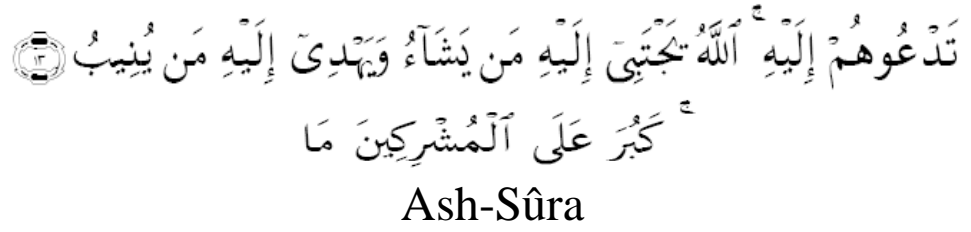

13- Intolerable for the Mushrikûn is that (Islamic Monotheism) to which you (O Muhammad) call them. Allah chooses for Himself whom He wills, and guides to Himself who turns to Him in repentance and in obedience. Kaan and Al-Hlali(1996)

Each tone group stands as a dependent tone group grammatically and semantically. The structure of the first tone group is $\mathrm{V}+$ prep phrase $+\mathrm{S}$ (relative pronoun) + Complement of the relative pronoun. The next tone group is compound sentences $\mathrm{S} 1+\mathrm{S} 2$, each of which consists of a topic $($ subject $)+$ predicate. The predicate in both sentences consists of a verb phrase. The utterance is complete. The division into tone groups in the Holy Quran is sometimes compulsory. The semantics and meaning play an important role in pausing, this can be seen in the following verse:

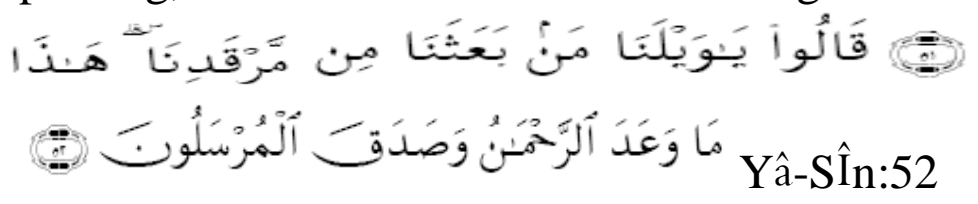


قالوا يا ويلنا من بعثنا من مرقدنال هذا ما وعد الرحمن وصدق المرسلون

52- They will say: 'Woe unto us! Who has raised us up from our place of repose." (it will be said to them ): "this is what the most Gracious (Allah) had promised, and the Messengers spoke the truth!" Kaan and Al-Hlali(1996)

This verse has one compulsory tone group division even it seems possible to make other divisions like:

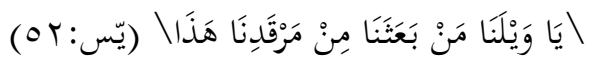

It is worth adding that in the Holy Quran there is a sign opposite this verse (or else a superscript at the end of the Word مَرْقَدِنَا 'our place of repose' which instructs the reader to

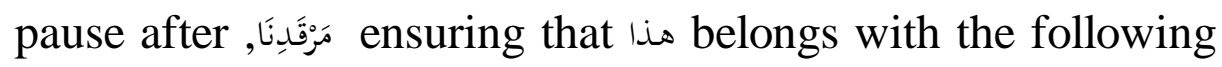
tone-group, and averting the above mentioned violation in the grammar and discourse of the verse.

In English, Cruttenden (1986) shows that there are some clauses or things less than a clause such as adverbials, nounphrase subjects, etc. that consistute separate tone-groups. The same thing can be seen in Arabic. In the Holy Quran there are some clauses or words such as vocative expressions, conjunctions, relative clauses, and interrogative.

\section{1- Vocatives.}

In the Holy Quran, the Vocative comes in the form of a pray by using the word Irabanal (Our Lord!), calling lyaal and call the person by his name directly.

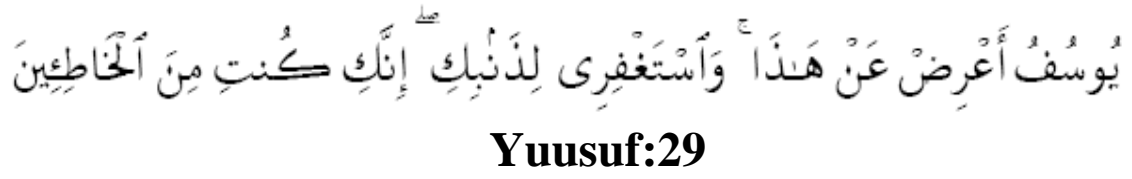

29- "O Yusuf (Joseph)! Turn away from this! (O woman)! Ask forgiveness for your sin. Verily, you were of the sinful." Kaan and Al-Hlali(1996)

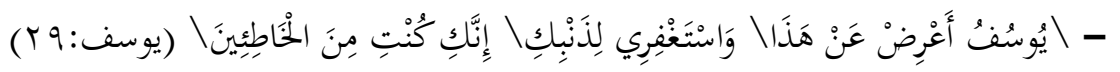


This verse is divided into three tone groups, the first tone group, is a vocative clause where Allah addresses his prophet Joseph," O Yusuf (Joseph)! Turn away from

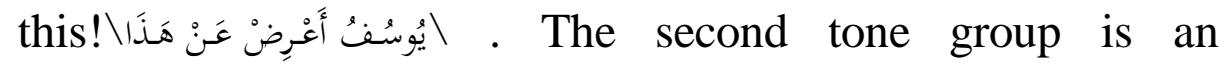

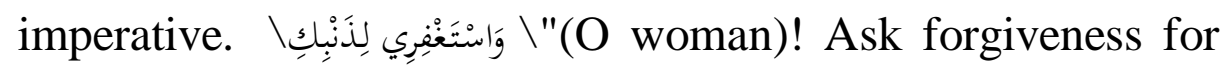
your sin". The third tone group is a NP which starts with the predicate إِنَّen nominal sentence.

\section{Conjunctions}

In Arabic, coordinating conjunctions play an important role in tone groups' division. They organize the ideas and their orders. There are several conjunctures as; \fa| 'then', IOummal "next, then, afterword' and Iwal. It is important to know that Iwal in Arabic has two main meanings which, makes it different from 'and' in English. One is to give the conjunction meaning where both ideas are related, the other use is when it gives an appellant meaning. These two different uses or meanings play an important role in tone groups division in the Holy Quran.

The following verse shows another Arabic conjunction;

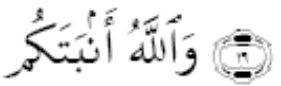

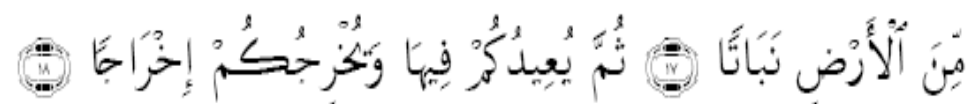

NoaH: 17-18

1- And Allah has brought you forth from the (dust of) earth.

2- Afterwards He will return you into it (the earth), and bring you forth (again on the Day of Resurrection). Kaan and Al-Hlali(1996)

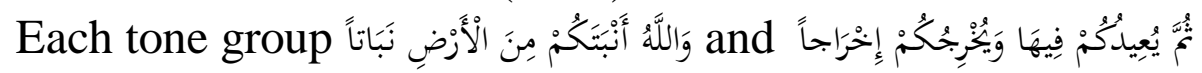

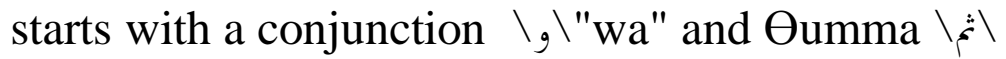




\section{Relative clauses:}

In Arabic relative clauses are used in order to separate between different utterances or to move from one story to another or from one topic to another. According to this, relative clauses cannot stand as a tone group or the speaker and the reader cannot stop on it.

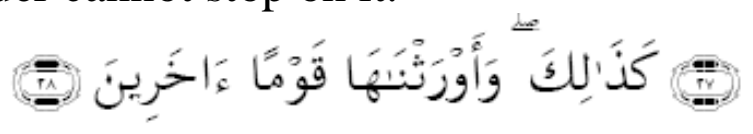

Ad-Dukhan:28

38- Thus (it was)! And We made other people inherit them (i.e. We made the Children of Israel to inherit the kingdom of Egypt). Kaan and Al-Hlali(1996)

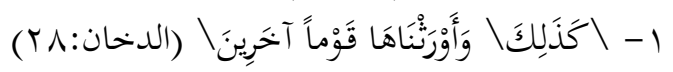

The pause on كذلك lkaðalikal 'thus' is optional pause \waqf jariz jawaazan mustawiya-l-Tarafayn \.

The pause on the relative clause in the Holy Quran depend strongly on the meaning that it reflects

\section{Complementizers and Particles}

In Arabic there are some particles which have initial position. According to its position and meaning, it governs the tone groups division in the utterance. Vis:

1- إِّ l?innal

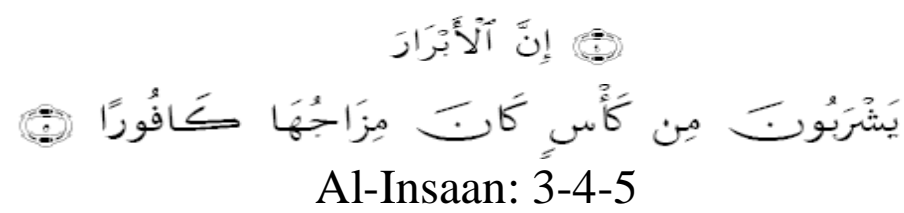

5- Verily, Al-Pabraar (the pious believers of Islamic Monotheism), shall drink of a cup (of wine) mixed with (water from a spring in paradise called) Kaafuur. Kaan and Al-Hlali(1996)

Tinna \ in initial position and this is the most common position for this sort of Particles like \?innal. We can see also 
that the tone group ends by the end of the NP which the particle \?innal precedes, as the following verses illustrate:

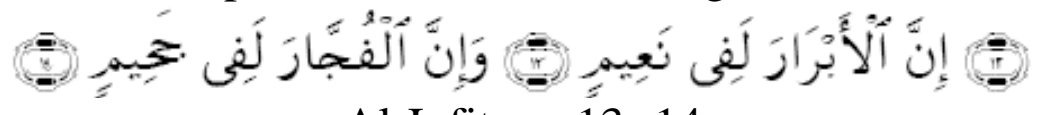

Al-Infitaar: 13- 14

\section{Tone-groups and meaning}

It is important for any Muslim to learn, even little, about the science of pausing and starting. So, any pausing or starting in reading the Holy Quran should agree with the Holy meaning. Arabs in general give intonation an important care this can be seen for example when Abu-Bakr Assedeeg asked a man who had a camel:

"أنبيعنيها "Tatabee9hal "will you sell it to me?"

The man replied:لا لاعافاك اله llaa 9aafak Allah\"No may God not bless you \"

Then Abu-Bakr told him not to say it like this but to say لا و عافاك اله ] ل اله wal wa afak Allahl] [No\ May God bless youl].

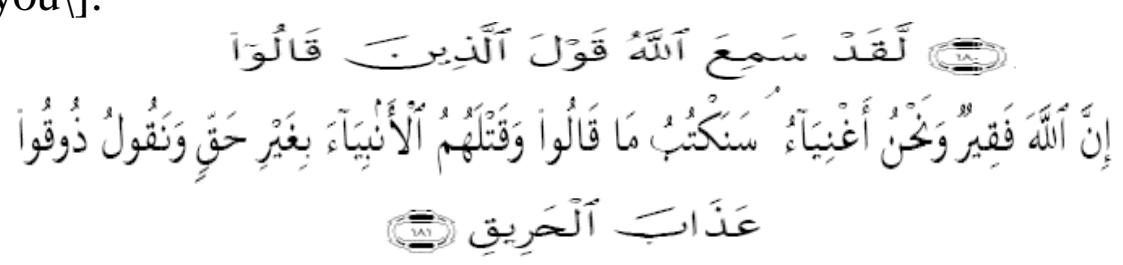

Al 9mran: 181

181- Indeed Allah has heard the statement of those (Jews) who say: "Truly, Allah is poor and we are rich!" We shall record what they have said and their killing of the prophets unjustly, and We shall say: "taste you the toment of the burning (fire)." Kaan and Al-Hlali(1996)

Tone groups division is as follows:

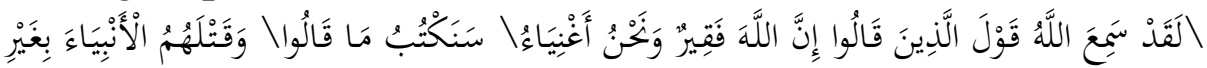

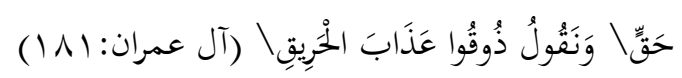


Pausing on the word أغنياء 'rich' is mandatory lal-waqf al-laaziml. Because the second tone group is an utterance said by Allah "We shall record what they have said", and if we continue reading it will refer to what Jew said. So the reader should adhere to this tone group division.

\section{The information unit in the tone groups of the Holy the Quran}

In the Holy Quran, tone groups play an important role in dialogue. This can be seen clearly in some verses where the tone group is more than one sentence. In long tone groups, the pause marks play an important role. That in some places the reader can not stop and if he stops he should repeat one or two words then continue the verse this is because of the meaning. Or as we will see in the following examples where the speaker will change if we pause or continue.

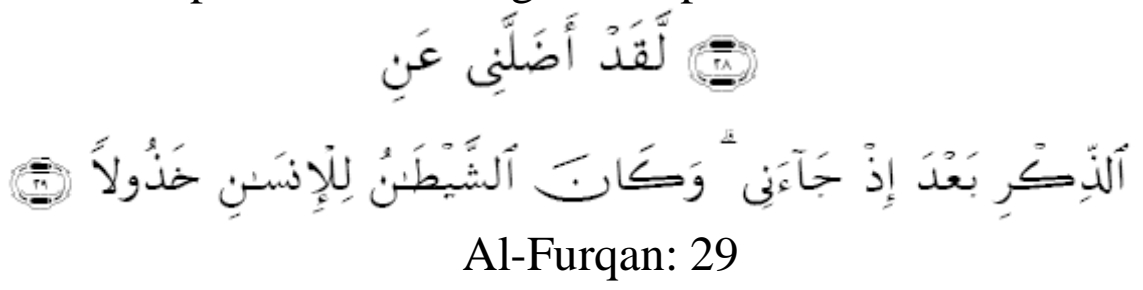

29- ' He indeed led me astray from the Reminder (this Quran) after it had come to me. And Shaitan (Satan) is to man ever a deserter in the hour of need." Kaan and AlHlali(1996)

This verse has two tone group divisions. The pause on جائن lja?anil "had come to me" is of preferred pause - \al-waqf jaa?iz wa awlaal.

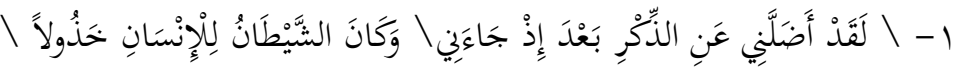

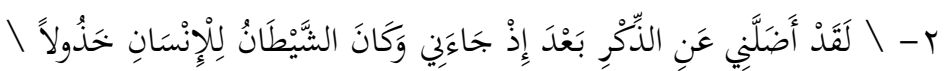

The second tone group in the first division is considered to be the utterance said by Allah which means that Satan is the one who makes 'Obai ibn Khalaf', whom the 
verse talks about, to be a friend of that person who led him astray.

According to the second tone group division, the whole utterance belongs to 'Obai ibn Khalaf' which means that; he describes his friend as Satan because he led him astray from following prophet Mohammed.

It is important here to give some attention to the importance of pause in discourse. \ALwaqf Al-Kafeel, in the Holly Quran, shows an important fact in discourse analysis. This fact shows how the utterance will change from one speaker to another through pausing.

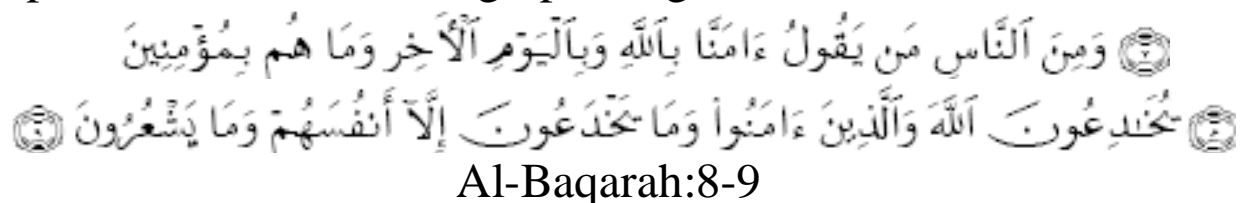

8- And of mankind, there are some (hypocrites) who say: "We believe in Allah and the Last Day' while in fact they believe not.

9-They (think to) deceive Allah and those who believe, while they only deceive themselves, and perceive (it) not! Kaan and Al-Hlali(1996)

In verse 8 the type of pause on 'وما هم بمؤمنين " is Iwaqf kafeel. Because if we continue reading, the following verse will be a descriptive sentence, that describes the word "بؤمنين" which negates the discretion of deception. The main meaning is to negate the description of belief and affirm the description of deception.

\section{Findings}

The study reveals that:

a- Tone groups align with larger syntactic constituents

b- In Each language tone groups correspond with clauses. The clause may be just a simple sentence or may be 
part of a compound or a complex sentence.

c- In many positions tone groups correspond with something less than clause, which sometimes modifies a whole clause, as vocative phrase, the particles as Tinnal in initial position, relative clause, conjunction phrases as \wal, \fa and \Өummal.

The meaning, which is the aim of speaking, instills tonegroup division. In many situations, the division of tone groups is determined by the meaning even if it is correct and complete grammatically.

\section{References}

Algeo, John. (1992).The Origins and Development of the English Language. Harcourt Brace \& company USA Amayreh, M. M. (1991). A Study of the Basic Intonational Patterns in Standard and Jordanian Arabic. M. A. Thesis, University of Jordan, Jordan.

Armstrong, L., \& Ward, C. (1931). $\underline{\text { A Handbook of English }}$ Intonation, Cambridge:

W. Heffer and Sons

Bolinger, Dwight, (1986). Intonation and its parts: Melody in spoken English. London: Edward Arnold.

Badawi, El Said. (1965). An Intonational Study of Colloquial Riyadhi Arabic. Unpublished Ph. D. Thesis, University of London, WG1.

Boomer, D. S. (1965). Hesitation and grammatical encoding. Language and Speech, 8, 148-58.

Brown. G. (1977). Listening to spoken Englsh. London.

Longman.

Brown. R.S.. (1978). Paratons: their reality and realization.

Report on Social Science Research Council Project HR 360. Dept. of linguistics, Edinburgh University.

Brown, G., Currie, K.L \& Kenworthy, J. (1980). Questions of Intonation. London: Helin. 
Carr, Philip. (1999). English Phonetics and Phonology.

Oxford: Blackwill Publishers Inc.

Coleman,H.O. (1914).Intonation and emphasis. Miscellanea

Phonetica I, International Phonetice Association, 6-26.

Chomsky, N. \& M. Halle. (1968). The sound pattern of

English. New York: Harper \&

Row.

Coulthard, Malcolm. (1977). An Introduction to Discourse

Analysis. London: Longman.

Cooper, John R. (1997). Intonation and Iambic Pentameter.

www.ebsco.com. Source: Papers on Language and

Literature, Vol. 33 Issue 4, p. 392.

Cruttenden, A. (1986). Intonation. Cambridge: Cambridge

University Press.

Crystal, David. (1969) Prosodic Systems and Intonation in

English. Cambridge University Press, London.

Crystal, D. and Quirk, R. (1964). Systems of Prosodic and

Paralinguistic Features in English. Mouton and Co.,

London.

El-Hassan, Shahir. (1991). Intonation-groups in English and

standard Arabic. Yarmouk University.

El-Menoufy, A.M. (1969) . A Study of the Role of Intonation

in the Grammar of English. Ph. D Thesis. University

of London.

Fox, Anthony. (1973). Tonesequences in English. Archivum

Linguisticum 4(new series):17-26.

Fox, Anthony(2000).Prosodic features and Prosodic

Structure, Oxford University press inc., New York.

Gleason, H. A. (1965). Linguistics and English Grammar.

New York: Holt, Rinehart and Winstron, Inc.

Gandour, Jack; Wong, Donald; Hsieh, Li; Weinzapfel, Bert;

Van Lancker, Diana; and Hutchins, Gary D. (2000). $\underline{A}$

Crosslinguistic PET38 Study of Tone Perception. 
www.ebsco.com. Source: Journal of Cognitive

Neuroscience, Jan (2000), Vol. 12 Issue 1, p207, 16p.

Halliday, Micheal A.K. (1961). Categories of the theory of

grammar. Word 17:241-92.

Halliday, M. A. K. (1967). Intonation and Grammar in

British English. The Hague: Mouton.

Halliday, M. A. K. (1970). A Course in Spoken English

Intonation. Oxford: Oxford University Press.

Kaan -Muhsin \&Al-Hlali- muhammed. (1996). The Noble

Quraan English Translationof the meanings and

commentary. King fahad Complex for the printing of

the Holy Quran. Al-Madinah Al-Munawarah, K.S.A.

Kingdon, R. (1958). The Groundwork of English Intonation.

Longman, London.

Klinghhardt, Hermann and FOURMESTRAUX, M. de

(1911). FranzÖsische IntonationsÜbungen.

Leipzig:CÖthen

Ladd, D. Robert. (1981). Intonational phrasing: the case for

recursive prosodic structure. Phonology Yearbook 3

printed in Great British University of Edinburgh.

Ladefoged, Peter. (1982). A Course in Phonetics. 2nd ed.

New York: Harcourt. Brace Jovanovich, Publishers.

Lehiste, Ilse. (1957). The phonetic structure of paragraphs.In

A. Cohen and S.G. Nooteboom (eds.), Structure and process in speech perception. Cambridge, MA:Springer, pp.195-203.

Lieberman, Philip. (1967). Intonation, Perception. And

Language. M.I.T. Press, Cambridge, Massachusetts.

Liberman, M. (1978). The Intonational System of Englis .

Unpublished Ph.D. Thesis, Massachusetts Institute of

Technology 
Ladd Robert. (1986). Intonational phrasing: the case for recursive prosodic structure,311-340. Phonology Yearbook3

Lindsey, G. A. (1985). Intonation and Interrogation: Tonal Structure and the Expression of a Pragmatic Function in English and Other Languages. Unpublished Ph. D. Thesis, University of California, Los Angeles.

MACCArthy, Peter (1975). The Pronunciation of German. London:Oxford University Press

O'Connor, J D. (1980). Better English Pronunciation.

Cambridge: Cambridge University Press.

O’Connor, J. D \& G. F. Arnold. (1973) Intonation of

Colloquial English. Second edition, London:

Longmans.

Palmer, F. R. (1970). Prosodic Analysis. Oxford University Press, London.

Pike, K. L. (1945). The Intonation of American English. University of Michigan Press, Ann Arbor.

Pike, K. L. (1995). The Intonation of American English. Ann Arbor: University of Michigan Press.

Schubiger, Maria. (1958). English intonation,its form and function. TÜbingen:Niemeyer.

Soraya, H. A. (1966). An Intonational Study of Egyptian Colloquial Arabic. Unpublished Ph. D. Thesis, University of London, London.

Taylor, David S. (1993). Intonation and Accent in English: What Teachers need to Know. Www.ebsco.com. Source: IRAL, February, Vol. 31 Issue 1, p. 1.

Tench, Paul. (1996). The Intonation Systems of English.

Cassell, London.

Wells, Rulon S. (1945). The pitch phonemes of English.

Language 21:27-39.

Yule, Leorge (1980) Speakers' Topics And Major 
Parathones, University of Edinburgh, Department of Linguistics North-Holland Publishing Company. http://humanities.byu.edu/ELC/teacher/Sectio.../AboutLangu ageQ ,2002

\section{Arabic References}

- النحاس أبي جعفر أحمد بن إسماعيل, إعراب القران الكريم المتوفى (TTK) تحقيق زهير غازي زاهد

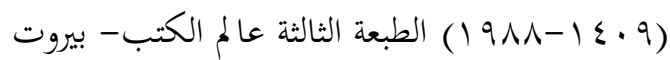

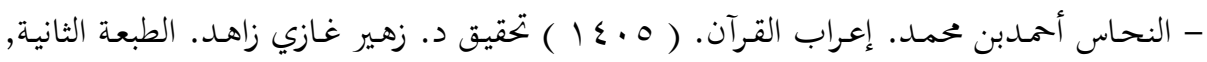
لعالم الكتب و مكتبة النهضه العربية.

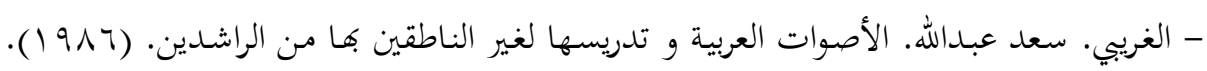
الطبعة الأولى مكة المكرمة: مكتببة الطالب الجامعي.

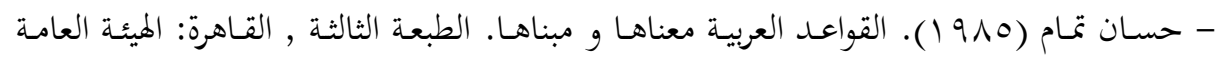
للطباعة

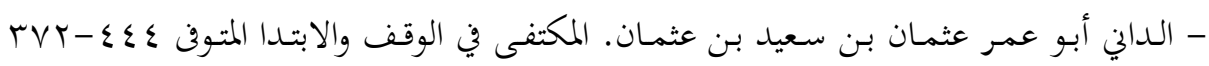

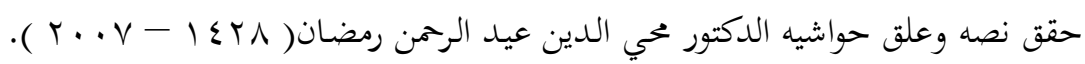
الطبعة الثانية عمان: دار عمار.

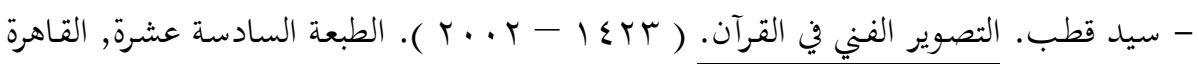

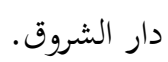

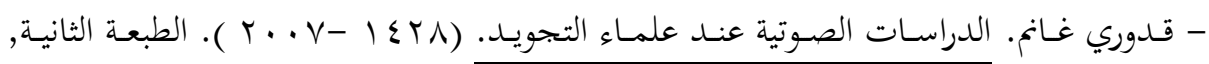

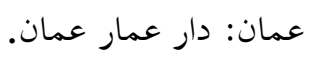



الظواهر الدلالية في كتاب إعراب القراءات والشواذ "لأبي البقاء العكبري"

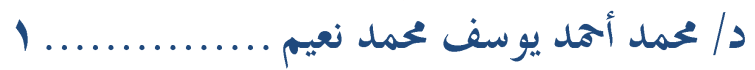

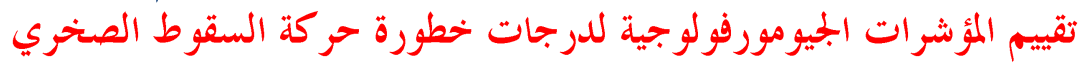

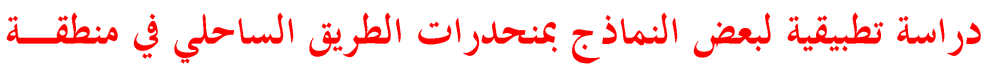

$$
\begin{aligned}
& \text { أ.د/ مني عبد الرحن يس الكيالي }
\end{aligned}
$$

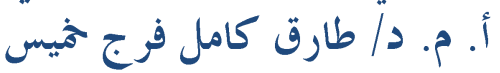

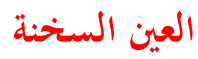

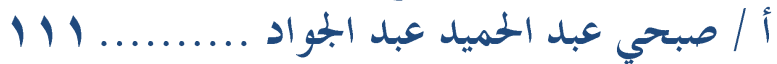

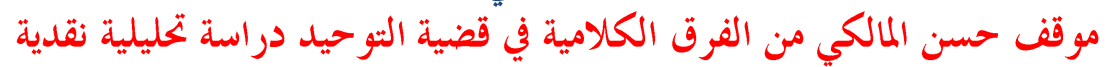
د/ الطالبة/ شريفة أحد المالكي .................

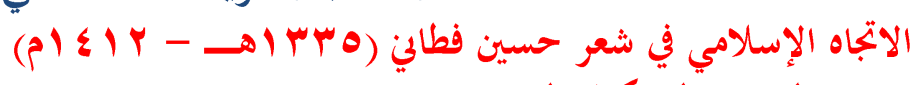

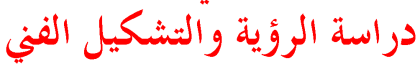

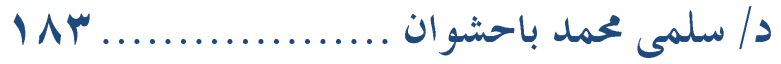

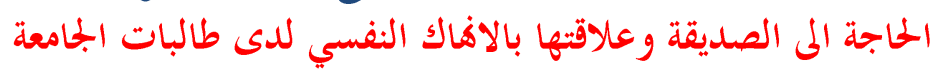

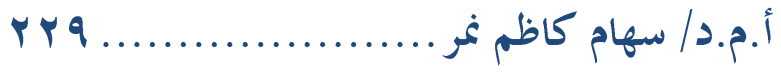

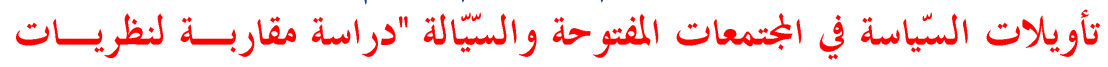

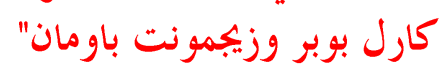

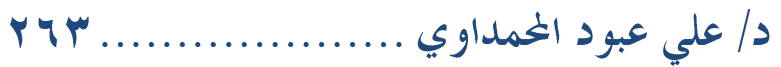

الأفعال الإنــــــــية في الأربعين النووية "دراسة تداولية" ديملية

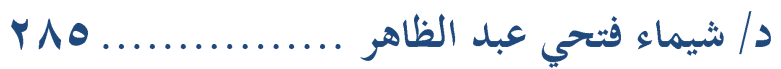

Title: Lexical Organization: "Sound Emission" Verbs

Dr. Salih Alzahrani..............................1

INTONATION GROUPS IN ARABIC (MAINLY IN

THE HOLY QURAN)

Dr. Areej Ali Otay.....

Voir, entendre et ressentir: à propos de l'écriture de Ce que j'appelle oubli de Laurent Mauvignier

Dr. Dalia Metawe 
من أعلى الضغوط النفسية والذي يؤثر على علاقات الفرد المختلفة وعلى تفاعلاته مـــع زملائسـهـ وأصدقائه والحاجة إلى صديقة بالنسبة لفتيات الجامعة.

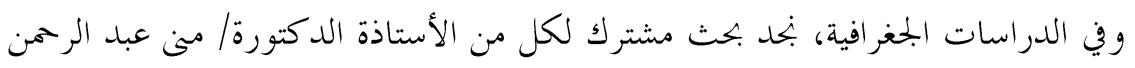

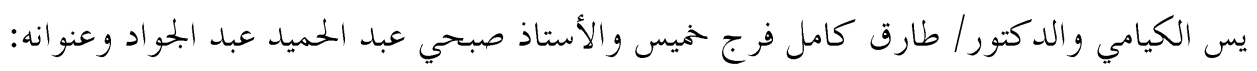

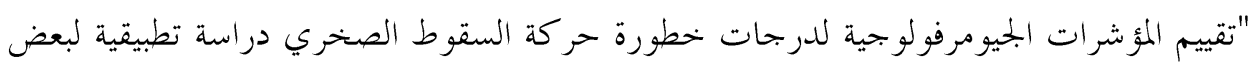

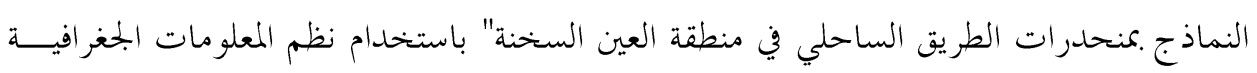

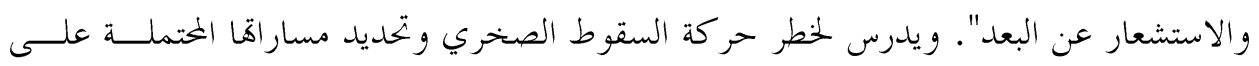

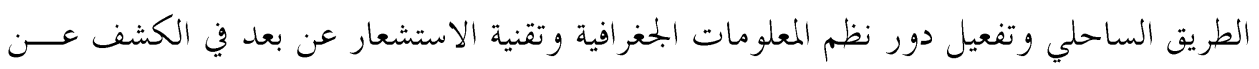
طبيعة منحدر ات تلك المنطقة.

و في مجال الإعلام يأتي بحث الدكتورة/ شيماء فتحي عبد الصادق تحــتـت عنـــوان: "دور

المسرح في علاج ذوي الاحتياجات الخاصة (مسرحية لسه متسماش لعاطف أبو شهبة) نموذجهـاً

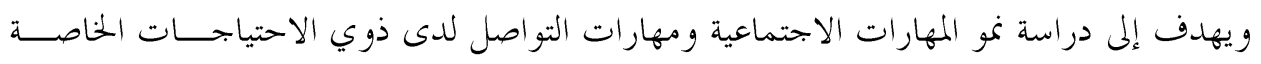

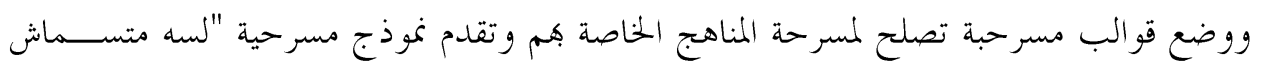
لعاطف أبو شهبة".

نائب رئيس بحلس الإدارة

$$
\text { أ.د / هناء زكريا }
$$

وكيل الكلية للدراسات العليا والبحوث 


\section{افتتاحية العلدد}

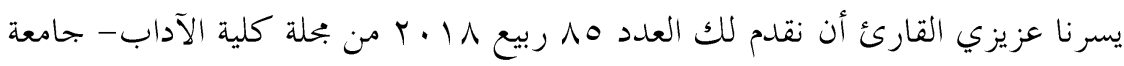

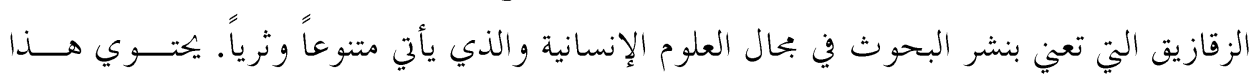

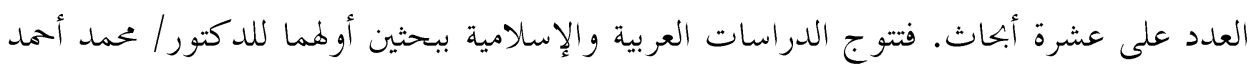

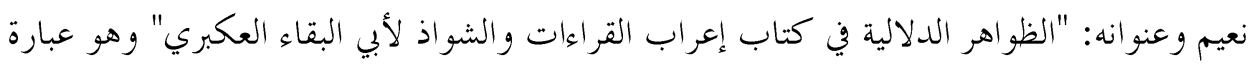

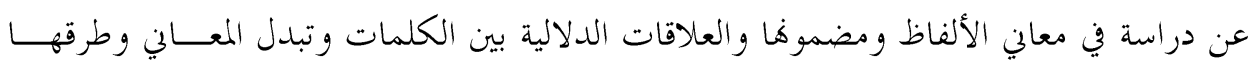

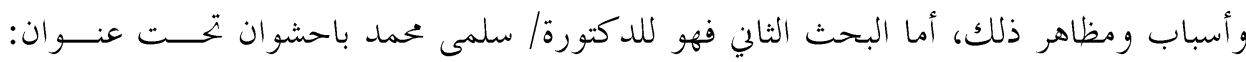

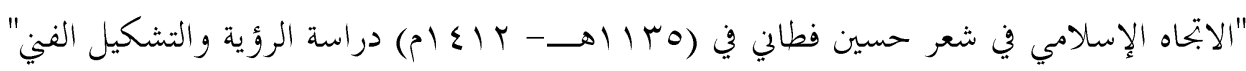
ويتناول الاتحاه الإسلامي في شعر حسين فطاني ودراسة في الرؤية والتشكيل لهذا الشاعر المكيّي.

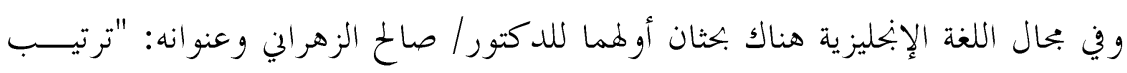

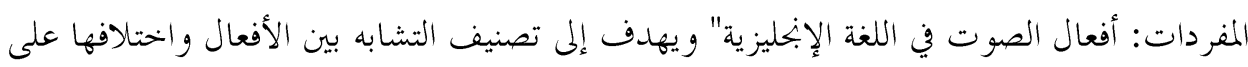

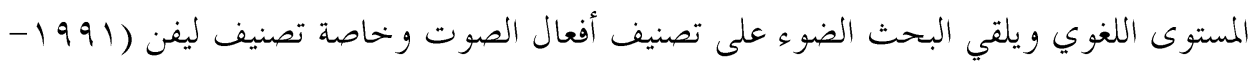

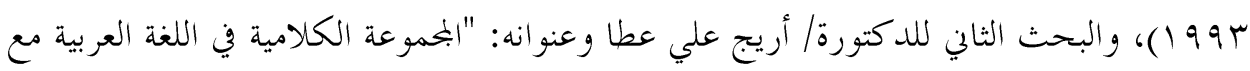

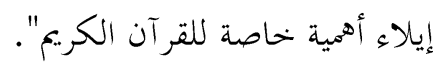

ويأتي بحث اللغة الفرنسية تحت عنوان: "نرى، نسمع، ونشعر فيما يتعلق بالكتابة في رواية

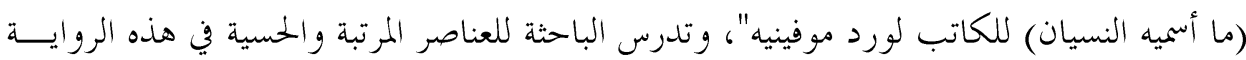
مع تحليل دورها في التنظيم النصي وتركيز الكاتب على العناصر البصرية والحسية وتعدد الحواس.

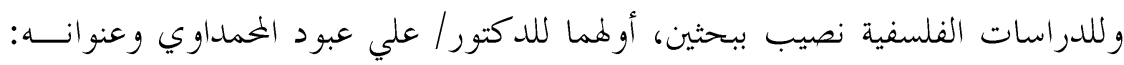

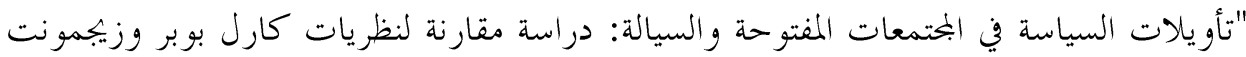

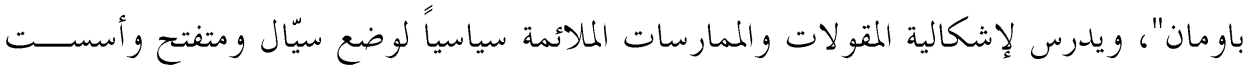

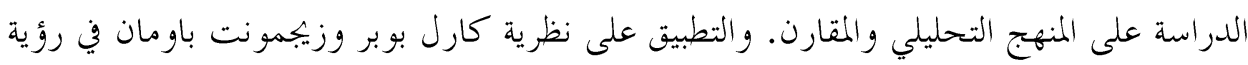

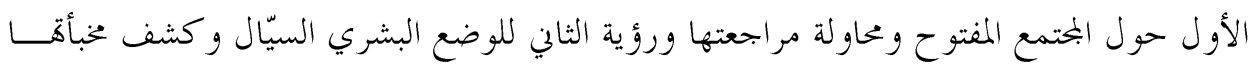

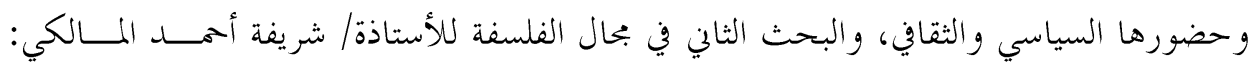

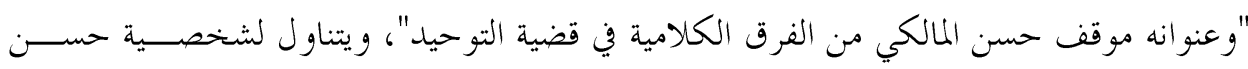

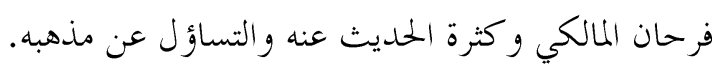
أما علم النفس فيتوّج ببحث للدكتورة/ سهام كاظم نمر وعنو انه: "الحاجة إلى صــديقة وعلاقتها بالإهاك النفسي لدى طالبات الجحامعة" والذي يهدف إلى دراسة الإناك النفسي الذي يعد مركد 

أسماء السادة الأساتذة همكمي هذا العدد ونقا للترتيب الأبجدي

أ.د/ أحمد سالم صالح

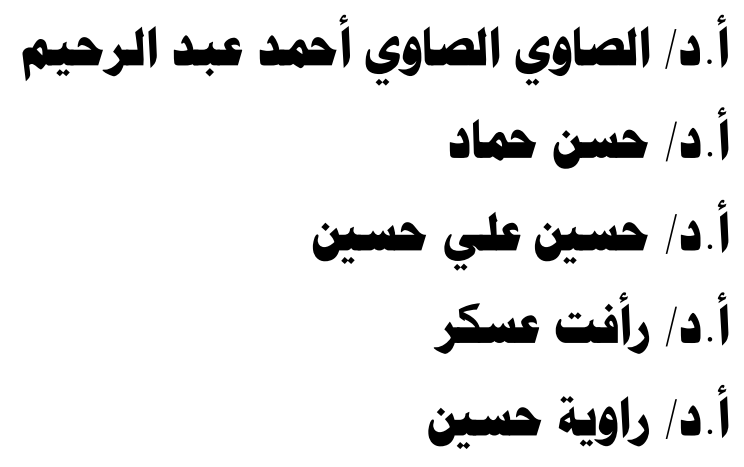
أ.د/ صابر عبد الدايتم يوسف رايه أ.د أد طارق زكريا علي

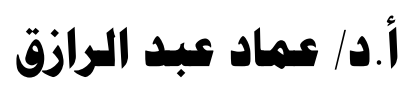
أ.د / لبنى عبد التواب يوسف

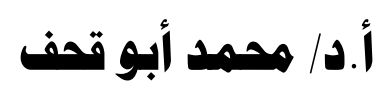

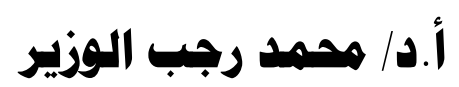

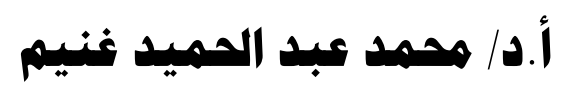
أ.د / هنى أحمد عبد العريز أ.د/ نادية أندراوس أهسي أ.د/ نازك همهد عبد اللطيف الديف أ.د/ نهوى عندس 



\section{هملة كلية \\ هبلة كلية الآداب - جامعة الزتقازيق \\ صدر العدد الأول 1917-17م له}

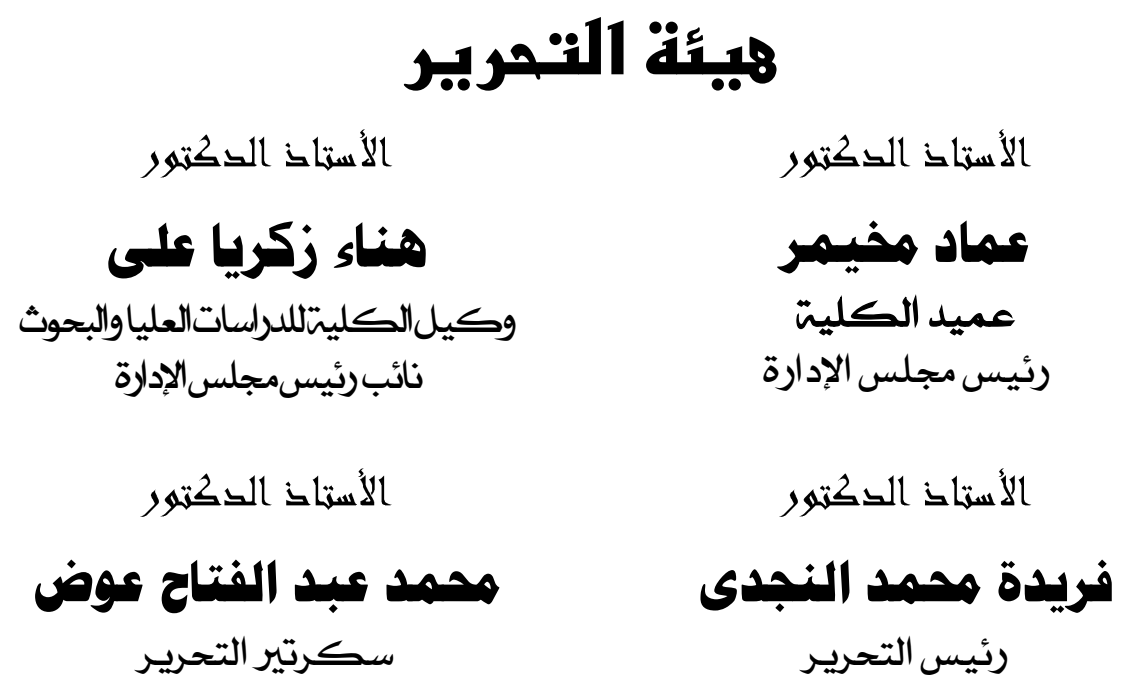

مستثنارو التحريز

أ.د . أحمــــد صـــلاح الـــدين

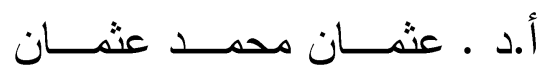

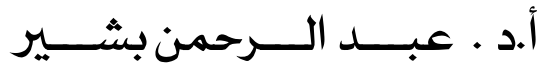

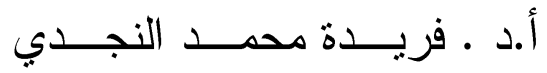

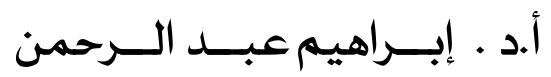

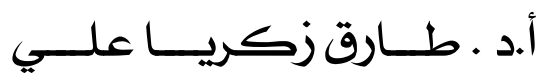

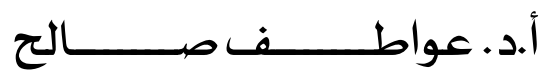

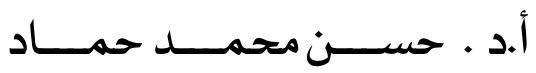

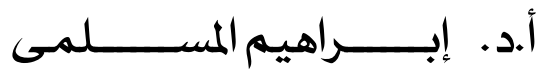


r ا - يرفق ملخصان للبحث باللغتين العربية والإنجليزية على ألا يتجاوز حجم الملخص صفحة واحدة.

با - تتشر المجلة ملخصات الرسائل العلمية العربية والأجنبية. ع ا- تنشر المجلة بحوث معاوني هيئة التدريس كمنطلب للحصول علـى درجني الماجسنير و الاكتور اه.

10 - تتشر المجلة بحوث أعضاء هيئة التدريس بدرجة أستاذ وفق القيمــة الفعلية للطباعة. 1 ا 1 - توجه جميع المكاتبات أو الاستفسار ات الخاصة بالنشر إلــى رئسبس تحرير المجلة على العنوان التالي.

\section{كلية الآداب - جامعة الزتقان النقيق}

تليفون :

http://www.Arts@Zu.edu.eg 
مجلة الكلية الآداب: فصلية- علمية- محكمة تعني بنشر الأبحاث العلمية في مجالات الدر اسة الإنسانية اللغوية و الأدبية و التاريخية و الجغر افية و الفلســفية الإدية

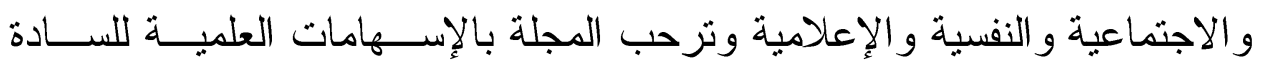

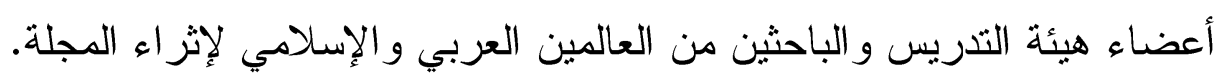

\section{قواعد النشئسر:-}

1- تقبل المجلة البحوث باللغات العربية والإنجليزية و الفرنسية.

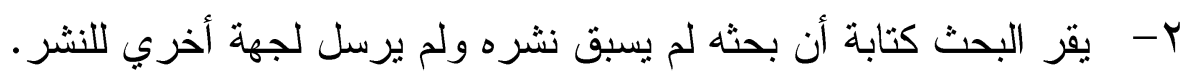

r- يخطر الباحث بخطاب رسمي بقبول النشر في حالة إجازة البحث للنشر .

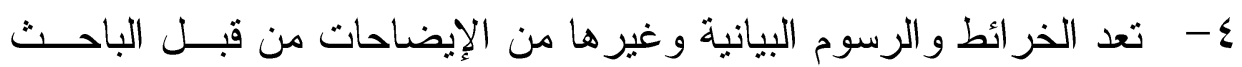

بطريقة تجعلها قابلة للطبع.

- - تعبر البحوث المنشورة عن رأي اصحابها فقط.

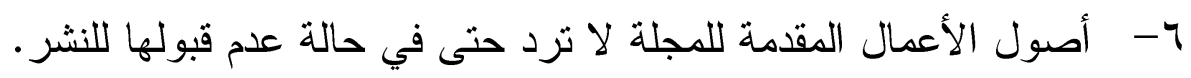

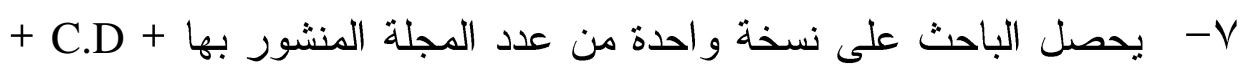
عشر مستلات من البحث.

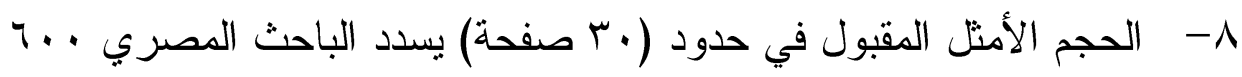

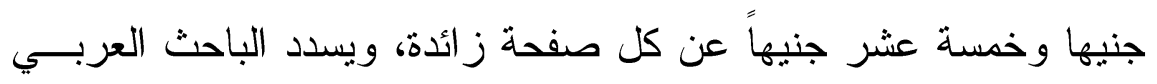
و الأجنبي ... ب دو لار وثثاثة دو لار عن كل صفحة زائدة. 9- يسلم البحث مطبوعاً من أصل وصورتين + C.D على أن يكون مجموعاً

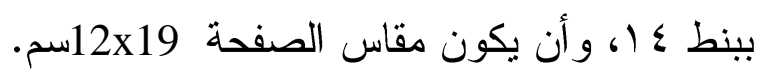

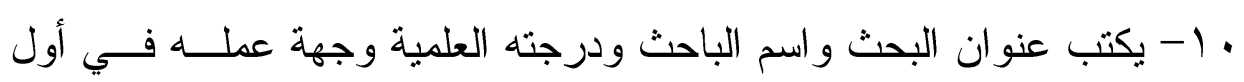
صفحة من البحث. 11 - تكتب المراجع و الهو امش في نهاية البحث، مع الالتز ام بالأسس العلميــة للتوثيق. 



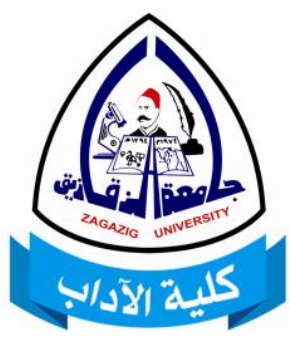

$$
\text { كلية الآداب مجلة }
$$

هملة علمية همكمة فمالية

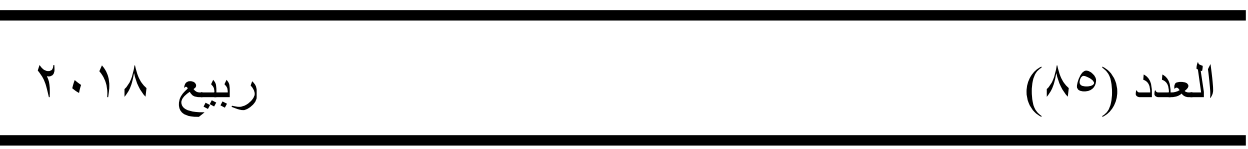

